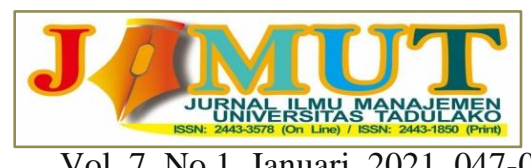

Vol. 7, No 1, Januari 2021, 047-057

\title{
PENGARUH LOKASI, PROMOSI DAN KUALITAS LAYANAN TERHADAP KEPUTUSAN BERBELANJA DI TRANSMART CARREFOUR PALU
}

\author{
oleh \\ AsrawatiNur \\ Asrawati nur. Zakiyah Zahara dan Muzakir Tombolotutu, \\ Fakultas Ekonomi, Jurusan Manajemen Universitas Tadulako, Palu \\ Email : asrawatisusan@gmail.com
}

\begin{abstract}
Indonesia is a developing country that builds its economy in two sectors of timber and goods that are ready to use, as for a business that is carried out by the Indonesian state, namely retail wholesale business. The presence of Transmart Carrefour in the city of Palu has become one of the places to shop that is able to meet the needs of the community This type of research is a descriptive study through a questionnaire and sampling techniques using purposive sampling with parametric statistical analysis methods of multiple linear regression. The results of this study indicate that simultaneously (simultaneously) Location, Sales Promotion and Service Quality significantly influence the Consumer Decision to Shop at the Carrefour Hammer and partially indicate that the Sales Promotion variable, service quality significantly influences the Consumer Decision to Shop at the Carrefour Transmart in Palu while the location variable partially does not significantly influence the Consumer Decision to Shop at Transmart Carrefour
\end{abstract}

Keywords: Location, Sales Promotion, Service Quality and Consumer Decisions.

\section{Abstrak}

Indonesia adalah negara berkembang yang membangun ekonominya di dua sektor kayu dan barang yang siap pakai, seperti untuk bisnis yang dilakukan oleh negara Indonesia, yaitu bisnis grosir eceran. Kehadiran Transmart Carrefour di Kota Palu telah menjadi salah satu tempat berbelanja yang mampu memenuhi kebutuhan masyarakat. Jenis penelitian ini adalah penelitian deskriptif melalui kuesioner dan teknik pengambilan sampel menggunakan purposive sampling dengan metode analisis statistik parametrik. regresi linier berganda. Hasil penelitian ini menunjukkan bahwa secara simultan (simultan) Lokasi, Promosi Penjualan dan Kualitas Layanan secara signifikan mempengaruhi Keputusan Konsumen untuk Berbelanja di Carrefour Hammer dan secara parsial menunjukkan bahwa variabel Promosi Penjualan, kualitas layanan secara signifikan mempengaruhi Keputusan Konsumen untuk Berbelanja di Carrefour. Transmart di Palu sedangkan variabel lokasi secara parsial tidak berpengaruh signifikan terhadap Keputusan Konsumen untuk Berbelanja di Transmart Carrefour Kata

kunci: Lokasi, Promosi Penjualan, Kualitas Layanan dan Keputusan Konsumen.

\section{PENDAHULUAN}

Indonesia negara berkembang yang membangun perekonomiannya didua sektor perkebuan maupun barang yang siap gunakan adapun suatu usaha yang lakukan oleh negara indonesia yaitu usaha grosir eceran. Usaha eceran grosir merupakan kegitan perekonomiaan menjadi sasaran penanaman modal bisnis ritel ,nama-nama perusahan ritel seperti Hypermarket, Giant dan Carrefour ialah pusat pembelanjayangdikenalluas dan nyaman beraneka. Kehadiran Transmart Carrefour di Kota Palu menjadi salah satu tempat berbelanja yang mampu memenuhi kebutuhan masyarakat, PT Transmart Ritail Indonesia membuka gerai pertaman nya diKota Palu pada tanggal 26 agustus 2014 dengan 
menghadirkan konsep pusat perbelanjaan keluarga yang menawarkan produk-produk berbelanja yang lengkap.

perusahaan beroperasi atau tempat perusahaan melakukan kegiatan untuk menghasilkann barang atau jasa yang mementingkan segi ekonominya" (Buchari Alma, 2003:103).

Kualitas layanan adalah tingkat keunggulan (excellence) yang diharapkan dan pengendalian atas keunggulan tersebut untuk memenuhi keinginan pelanggan (Tjiptono dalam Cristiani D. Manengal, 2015:2).

\section{KAJIAN LITERATUR}

\section{Manajemen Pemasaran}

Menurut Kotler dan Keller (2009:5), manajemen pemasaran adalah ilmu agar bisa mendapatkan kemampuan untuk dapat memilih sasaran pasar dan kemudian meraih, mempertahankan, dan menambah pelanggan-pelanggan baru dengan cara mengantarkan, lalu mengkomunikasikan nilai pelanggan yang unggul.

\section{Promosi Penjualan}

Pada suatu kegiatan dari pemasaran tujuannya adalah untuk melangsungkan pertukaran, Kotler (2003) yaitu proses sosial, personal dankelompok untuk memperoleh apa yang dibutuhkan dan diinginkan oleh para konsumen dengan cara menciptakan lalu kemudian mempertahankan nilai dariproduk atau jasa yang ditawarkan.

Jasa pelayanan merupakan salah satu strategi yang sangat berpengaruh dalam memenangkan persaingan Menurut Hutt dan Speh dalam Nasution (2004:47), ada tiga dimensi utama dari kualitas layanan, pertama adalah bagaimana kualitas produk atau jasa yang diterima konsumen. Kedua adalah bagaimana cara menyampaikan kepada konsumen tentang kualitas dari produk atau jasa yang ditawarkan. Ketiga adalah Corporate image yaitu reputasi, citra dari perusahaan, daya tarik yang dimiliki perusahaan.

\section{Keputusan Pembelian}

Menurut Sangadji dan Sophia (2013:121) dalam bukunya mengatakan bahwa perilaku konsumen ialah ketika seorang konsumen memilih satu tindakan diantara banyaknya tindakan alternatif yang lain. Kotler dan Keller, (2009:240) mengatakan keputusan seorang konsumen adalah keputusan konsumen mengenai merek-merek yang ada di dalam kumpulan pilihan.

\section{METODE PENELITIAN}

\section{Jenis Penelitian}

Jenis penelitian yang digunakan dalam penelitian ini adalah deskriptif dan kuantitatif. Penelitian deskriptif artinya memberikan pemaparan dalam bentuk interpretasi dalam pengaruh lokasi, promosi penjualan serta kualitas layananterhadap keputusan konsumen berbelanja di Transmart Carrefour Kota Palu.

\section{Lokasi Penelitian}

Tempat penelitian ini berada di Transmart Carrefour Kota Palu.

\section{Jenis Data Dan Sumber Data}

\section{Jenis Data}

Menurut Kuncoro (2009:148) jenis data menurut sumbernya terdiri dari dataprimer dan data sekunder : 
1. Data primer merupakan data yang didapat dengan cara melakukan survey langsung ke lapangan dengan menggunakan metode pengumpulan data original (Kuncoro, 2009:148). Data primer yang digunakan dalam penelitian ini adalah data yang didapatkan secara langsung dari konsumen melalui observasi, wawancara, dan pengisian koesioner tentang tanggapan dan pendapat partisipan.

2. data sekunder adalah data yang telah dikumpulkan oleh lembaga pengumpul data dan dipublikasikan kepada masyarakat pengguna data. dalam penelitian ini data sekunder yaitu data yang didapat dari perusahaan terkait serta data dari internet serta buku-buku yang tersedia diperpustakaan yang terkait dalam penelitian ini.

\section{Metode Pengumpulan Data}

Cara pengumpulan data yang digunakan pada penelitian yaitu:

1. Observasi : yaitu dengan cara melakukan penelitian secara langsung terhadap objek yang diteliti, dalam hal ini keputusan konsumen berbelanja di Transmart Carrefour Kota Palu yang dijadikan sampel untuk memperoleh informasi yang berhubungan dengan penelitian ini.

2. Wawancara : yaitu dengan cara melakukan Tanya jawab secara langsung kepada konsumen yang sedan g berbelanja di Transmart Carrefour Kota Palu yang dijadikan sampel untuk memperoleh informasi yang berhubungan dengan penelitian ini.

3. Kuesioner : metode pengumpulan data dengan cara mengedarkan daftar pertanyaan kepada responden yang terpilih sebagai sampel dalam penelitian ini.

\section{Populasi Penelitian dan Teknik Pengambilan Sampel}

Populasi yang dimaksudkan dalam penelitian ini adalah Populasi pada penelitian ini yaitu konsumen yang berbelanja di Transmart Carrefour Kota Palu.Pada penelitian ini penulis menetapkan jumlah sampel sebesar4x21 variabel yaitu 80 responden. Berdasarkan hal ini maka sampel dari penelitian inisebanyak 80 responden.

\section{HASIL DAN PEMBAHASAN}

\section{Karakteristik Responden}

Karakteristik responden berdasarkan hasil survey yang dilakukan pada 80 responden pengunjung yang berbelanja di Transmart Carrefour Palu. Karakteristik umum tersebut terdiri jenis kelamin, usia, pendapatan, dan pekerjaan.

\section{Tabel 1}

\section{Karakteristik Responden Berdasarkan Kelompok jenis kelamin}

\begin{tabular}{|c|r|r|r|r|}
\hline & Frequency & Frequency & Percent & $\begin{array}{c}\text { Valid } \\
\text { Percent }\end{array}$ \\
\hline Pria & 37 & 37 & 46.2 & 46.2 \\
\hline wanita & 43 & 43 & 53.8 & 53.8 \\
\hline total & 80 & 80 & 100.0 & 100.0 \\
\hline
\end{tabular}

Sumber data diolah

Berdasarkan Tabel 1 bahwa dalam penelitian ini jumlah jenis kelamin responden yang berkunjung di Transmart Carrefour Palu. oleh jenis kelamin perempuan dengan persentase sebesar 53,8 \%. Jadi dapat disimpulkan bahwa responden dalam penelitian ini jenis kelamin perempuan jauh lebih besar. 
Tabel 2

Karakteristik berdasarkan tingkat usia

\begin{tabular}{|c|c|c|c|c|}
\hline 17tahun & Frequency & Percent & Valid Percent & $\begin{array}{c}\text { Cumulative } \\
\text { Percent }\end{array}$ \\
\hline 20tahun -25tahun & 1 & 1.2 & 1.2 & 1.2 \\
\hline 30 tahun- 35 tahun & 29 & 36.2 & 36.2 & 37.5 \\
\hline 35 tahun -40 tahun & 19 & 23.8 & 23.8 & 61.2 \\
\hline$>45$ tahun & 26 & 32.5 & 32.5 & 93.8 \\
\hline Total & 5 & 6.2 & 6.2 & 100.0 \\
\hline 17tahun & 80 & 100.0 & 100.0 & \\
\hline
\end{tabular}

Sumber data diolah

Berdasarkan tabel 2. Hasil analisis untuk karakteristik usia didapatkan bahwa konsumen Transmart Carrefour adalah 36.2 persen berada pada usia 20-25 tahun, 1.2 persen pada usia 17 tahun , 23,8 persen pada usia $30-35$ tahun, 32,5 persen . dan $>45$ tahun 6.2 persen.

\section{Karakteristik reponden berdasarkan pendidikan}

Berdasarkan hasil penelitian diketahui tingkat pendidikan responden/pegunjung bervariasi. Secara rinci karakteristik responden berdasarkanpendidikan dapat dilihat pada tabel berikut :

Tabel 3

Karakteristik reponden berdasarkan pendidikan

\begin{tabular}{|l|r|r|r|r|}
\hline & \multicolumn{1}{|c|}{ frequency } & \multicolumn{1}{c|}{ percent } & \multicolumn{1}{c|}{$\begin{array}{c}\text { valid } \\
\text { percent }\end{array}$} & $\begin{array}{c}\text { cumulative } \\
\text { percent }\end{array}$ \\
\hline sltp/mts & 9 & 11.2 & 11.2 & 11.2 \\
\hline sma/smk & 25 & 31.2 & 31.2 & 42.5 \\
\hline diploma & 27 & 33.8 & 33.8 & 76.2 \\
\hline sarjana & 11 & 13.8 & 13.8 & 90.0 \\
\hline $\begin{array}{l}\text { pasca } \\
\text { sarjana }\end{array}$ & 8 & 10.0 & 10.0 & 100.0 \\
\hline
\end{tabular}

Sumber data diolah

Hasil analisis untuk karakteristik tingkat pendidikan konsumen. didapatkan bahwa mayoritas tingkat pendidikan konsumen Transmart Carrefour kota Palu . didominasi oleh lulusan DIPLOMA sebesar33.8 persen. kemudian sisanya adalah lulusanSMA/SMK sebesar 31.2persen, lulusan SARJANA sebesar 13,8 persen, lulusan SLTP/MTS sebesar 11.2persen, lulusan pasca sarjana sebesar 10 persen, dan lulusan SD sebesar 0 persen.

Tabel 4

Karakteristik reponden berdasarkan pendapatan

\begin{tabular}{|c|c|c|c|}
\hline 1juta-2juta & 17 & 21.2 & 21.2 \\
\hline 2juta-3juta & 28 & 35.0 & 35.0 \\
\hline 3juta-4juta & 18 & 22.5 & 22.5 \\
\hline 4juta -5 juta & 9 & 11.2 & 11.2 \\
\hline$>$ 5juta & 8 & 10.0 & 10.0 \\
\hline Total & 80 & 100.0 & 100.0 \\
\hline
\end{tabular}

Sumber data diolah

Hasil Analisis Deskriptif Tersebut Juga Menunjukkan Bahwa Carrefour Memiliki Konsumen Dari Berbagai Lapisan Masyarakat Yaitu Bawah, Menengah, Dan Atas. Hal Ini Dapat Dilihat Dari Hasil Persentase Yang Cukup Merata Antara Kategori Pendapatan. Carrefour Memang Menyediakan Produk-Produk Dengan Harga Yang Bersaing. 


\section{Tabel 5}

Karakteristik Responden Berdasarkan Pekerjaan

\begin{tabular}{|l|r|r|r|r|}
\hline & Frequency & \multicolumn{1}{c|}{ Percent } & Valid Percent & $\begin{array}{c}\text { Cumulative } \\
\text { Percent }\end{array}$ \\
\hline $\begin{array}{l}\text { ibu rumah } \\
\text { tangga }\end{array}$ & 20 & 25.0 & 25.0 & 25.0 \\
\hline mahasiswa & 19 & 23.8 & 23.8 & 48.8 \\
\hline Swasta & 18 & 22.5 & 22.5 & 71.2 \\
\hline Pns & 6 & 7.5 & 7.5 & 78.8 \\
\hline Dll & 17 & 21.2 & 21.2 & 100.0 \\
\hline
\end{tabular}

Sumber data diolah

Berdasarkan Analisis tersebut maka jumlah konsumen terbanyak Carrefour adalah ibu rumah tangga, mahasiswa dan bekerja di swasta. Hal tersebut dapat dimanfaatkan Carrefour untuk lebih meningkatkan promosi pada produk-produk keperluan rumah tangga dan kebutuhan sehari - hari. Sedangkan keperluar pada mahasiswa dan pekerja swasta yang berkaitan dan menunjang pekerjaan mereka seperti pakaian kerja, ikat pinggang, dasi, perlengkapan kantor, dan lain-lain

Tabel 6

\section{Karaterstik Reponden Berdasarkan Perencanaan Berbelanja}

\begin{tabular}{|c|c|c|c|c|}
\hline & Frequency & Percent & $\begin{array}{c}\text { Valid } \\
\text { Percent }\end{array}$ & $\begin{array}{c}\text { Cumulative } \\
\text { Percent }\end{array}$ \\
\hline $\begin{array}{c}\text { Selalu } \\
\text { (Kadang) } \\
\text { Direncanakan }\end{array}$ & 20 & 25.0 & 25.0 & 25.0 \\
\hline $\begin{array}{c}\text { Tidak } \\
\text { Direncanakan }\end{array}$ & 30 & 37.5 & 37.5 & 62.5 \\
\hline Direncanakan & 30 & 37.5 & 37.5 & 100.0 \\
\hline Total & 80 & 100.0 & 100.0 & \\
\hline
\end{tabular}

Sumber data diolah

Pihak Carrefour dapat memanfaatkan peluang karakteristik perencanaan belanja konsumen dengan cara membuat program-program yang dapat menimbulkan dan meningkatkan pembelian. Oleh karena itu, diharapkan mereka akan tertarik untuk membeli produk yang tidak direncanakan sebelumnya atau membeli produk yang jenisnya sudah mereka rencanakan sebelumnya tetapi merek dari produk tersebut belum ditentukan. Program-program tersebut dapat berupa kegiatan promosi penjualan di dalam toko yang menarik perhatian konsumen, memajang produk dengan display atau tampilan rak yang menarik perhatian dan mudah dijangkau, dan sebagainya.

\section{Uji Asumsi Klasik}

Kelayakan dari suatu regresi linear berganda yang digunakan dalam penelitian ini, maka model tersebut haruslah memenuhi persyaratan dari uji asumsi klasik, seperti uji multikolinieritas, uji heterokedastisitas, dan uji normalitas.

\section{a. Uji Normalitas}

Uji normalitas data dimaksudkan untuk mengetahui apakah terdapat data berdistribusi normal atau tidak. Uji normalitas data dilakukan dengan menggunakan SPSS 16.0, yaitu dengan melihat sebaran data pada garis diagonal. Sebaran data berada dan mengikuti arah garis diagonal, maka model regresi mengikuti asumsi normalitas. 


\section{Gambar 1}

\section{Uji Normalitas Variabel Dependent Keputusan Konsumen (Y)}
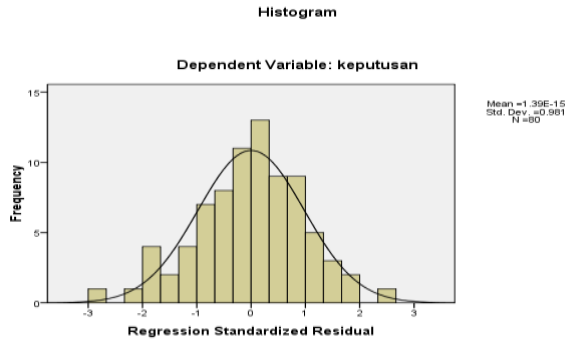

Sumber Data Diolah

Gambar 5.2

Uji Variabel Dependen Keputusan Konsumen (Y)

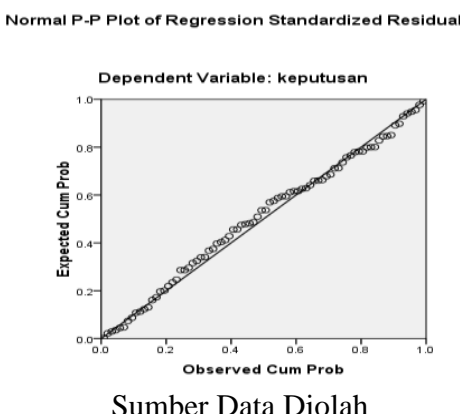

Hasil pengujian menunjukan bahwa tampilan grafik yang memberikan pola distribusi titik plot yang cenderung tersebar mendekati atau berada disekitar garis diagonal dan mengikuti arah garis diagonal. Sedangkan grafik histrogram menunjukan pola distribusi normal sehingga dapat disimpulkan asumsi normalitas dikatakan dapat terpenuhi.

\section{Uji Multikolinearitas}

Uji multikolinearitas bertujuan untuk menguji apakah model regresi ditemukan adanya korelasi atas variabel bebas (independen). Model regresi yang baik seharusnya bebas multikolinieritas atau tidak terjadi kolerasi diantara variabel independen.untuk mengetahui ada tidaknya multikolinieritas tersebut dalam suatu model regresi berganda dapat dilihat melalui (1) nilai Tolerance dan lawannya (2) Variance Inflation Factor (VIF).

Tabel 7

Hasil Uji Multikolineritas Dengan Menggunakan Nilai Tolerance Dan VIF

\begin{tabular}{|c|c|c|c|}
\hline \multirow{2}{*}{ Model } & \multirow{2}{*}{ Variabel } & \multicolumn{2}{|c|}{ Collinearity statistic } \\
\cline { 3 - 4 } & (constant) & Tolerance & VIF \\
\hline & Lokasi & 936 & 1.068 \\
\hline & $\begin{array}{l}\text { Promosi } \\
\text { penjualan }\end{array}$ & 970 & 1.032 \\
\hline & Kualitas layanan & 925 & 1.081 \\
\hline
\end{tabular}

Sumber data diolah 


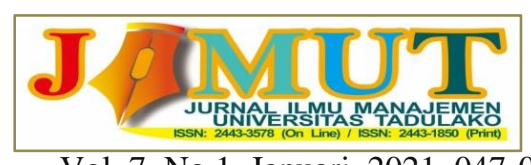

Vol. 7, No 1, Januari 2021, 047-057

Hasil perhitungan nilai tolerance pada tabel 5.8 menunjukan bahwa tidak ada variabel independen yang memiliki nilai tolerance lebih dari 0,10 dengan demikian tidak ada variabel yang memiliki nilai lebih dari 95\%. Demikian juga dengan nilai perhitungan VIF (variance inflation factor), menunjukan bahwa tidak ada satu variabel yang mempunyai nilai $>10$. Maka dengan demikian dapat disimpulkan bahwa dalam model tidak terdapat multikolinieritas yang serius.

\section{Uji Heteroskedastisitas}

Uji heteroskedastisitas bertujuan untuk mendeteksi apakah varians dari kesalahan pengganggu konstan untuk semua variabel penjelas. Bila ditemukan varians dari kesalahan pengganggu tersebut tidak konstan, berarti dalam model yang digunakan terdapat gejala heteroskedastisitas.

\section{Gambar 3}

\section{Uji Heteroskedastisitas Variabel Dependent (Y)}

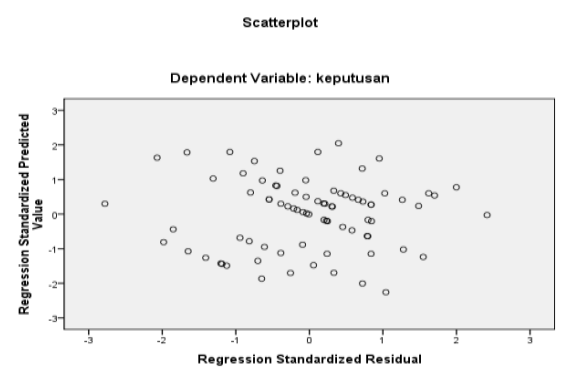

Sumber data diolah

Gambar 3 bahwa titik-titik menyebar secara acak serta tersebar baik diatas maupun dibawah angka 0 pada sumbu Y. Dapat disimpulkan bahwa tidak terjadi heteroskedastisitas pada model regresi, sehingga model regresi layak dipakai untuk nenprediksi keputusan konsumen berdasarkan variabel lokasi promosi penjualan dan kualitas layanan.

\section{Hasil Analisis Regresi Linear Berganda}

Analisis regresi linear berganda adalah alat analisis statistik yang memberikan penjelasan tentang pola hubungan (model) dan pengaruh antara dua variabel atau lebih penelitian yang berbeda melalui beberapa hasil observasi diberbagai bidang kegiatan. Berkaitan dengan penelitian ini, alat Analisis Statistik parametrik Regresi Linear Berganda digunakan untuk mengukur hubungan dan pengaruh dari variabel bebas (independent) yaitu lokasi promosi penjualan dan kualitas layanan.

\section{Tabel 8}

\section{Hasil Perhitungan Regresi Linear Berganda}

\begin{tabular}{|c|c|c|c|c|c|c|}
\hline \multirow[t]{2}{*}{ No } & \multirow[t]{2}{*}{ Variabel Independent } & \multicolumn{2}{|c|}{$\begin{array}{l}\text { Unstandardized } \\
\text { Coefficients }\end{array}$} & \multirow[t]{2}{*}{$t_{\text {hitung }}$} & \multirow[t]{2}{*}{ Sig-t } & \multirow{2}{*}{$\begin{array}{c}\mathrm{r}^{2} \\
\text { partial }\end{array}$} \\
\hline & & B & Std.Error & & & \\
\hline 1. & \multirow{2}{*}{$\begin{array}{c}\text { lokasi }\left(\mathrm{X}_{1}\right) \\
\text { Promosi penjualan }\left(\mathrm{X}_{2}\right)\end{array}$} & 664 & 062 & 10.737 & 000 & 776 \\
\hline 2. & & 173 & 075 & 2.312 & 023 & 256 \\
\hline 3. & Kualitas Layanan $\left(\mathrm{X}_{3}\right)$ & 186 & 084 & 2.210 & 0,30 & 246 \\
\hline \multicolumn{7}{|c|}{ Contanta $\quad=2.1271$} \\
\hline \multicolumn{2}{|c|}{ R-Squared $\left(\mathrm{R}^{2}\right)=0,789$} & \multicolumn{2}{|c|}{ Sig: $0,000^{\mathrm{a}}$} & & & \\
\hline \multicolumn{4}{|c|}{ Multipler R $=0,623$} & & & \\
\hline
\end{tabular}

Sumber data diolah

Berdasarkan hasil analisis regresi linear berganda dalam Tabel 5.10, bila dimasukan ke dalam model persamaan regresi linear berganda, maka dapar dibuat bentu persamaan sebagai berikut : 
Koefisien regresi dalam bentuk persamaan dapat dijelaskan sebagai berikut:

1) Nilai konstanta memiliki nilai 2.1271 hal ini berarti jika variabel $\mathrm{X} 1, \mathrm{X} 2$, X3 dianggap konstan atau tidak mengalami perubahan (bernilai 0) maka variabel lokasi promosi penjualan dan kualitas layanan keputusan konsumen berbelanja memiliki nilai tetap positif 0,1988

2) Variabel Lokasi $\left(\mathrm{X}_{1}\right)$ mempunyai koefisien sebesar 0,664 dengan arah positif, artinya jika variabel meningkat, maka keputusan Konsumen mengalami peningkatan.

3) Variabel Promosi Penjualan $\left(\mathrm{X}_{2}\right)$ mempunyai koefisien sebesar 0,173 dengan arah positif, artinya jika variabel promosi penjualan meningkat, maka Keputusan Konsumen juga mengalami peningkatan.

4) Variabel Kualitas Layanan $\left(\mathrm{X}_{3}\right)$ mempunyai koefisien sebesar 0,186 dengan arah positif, artinya jika variabel kualitas layanan meningkat, maka keputusan Konsumen juga mengalami peningkatan.

5) Nilai kofisien korelasi (R) yaitu sebesbar 0,623 . Nilai $R$ berkisar antara 0 sampai 1 apabila nilai $R$ mendekati 0 maka hubungnan antara variabel semakin rendah. Apabilah nilai $\mathrm{R}$ mendekati 1 persen maka hubungan antara variabel semakin tinggi. Nilai pada penelitian ini adalah 0,623 menunjukan bahwah hubungan antara variabel lokasi, promosi penjualan,kualitas layanan terhadap keputusan konsumen adalah mendekati tinggi.

\section{Pengujian Hipotesis}

\section{Hasil Uji Simultan (Uji F)}

Uji simultan dilakukan untuk mengetahui apakah variabel indipenden atau variabel bebas (lokasi , promosi penjualan, kualitas layanan) berpengaruh secara simultan terhadap variabel dependen atau variabel terikat (keputusan konsumen) berbelanja di Transmart kota palu. Hasil uji F ditampilkan seperti tabel dibawah ini :

Tabel 9

Hasil Pengujian Secara Simultan (uji F)

\begin{tabular}{|l|l|r|r|r|l|}
\hline Model & Sum of Squares & df & $\begin{array}{c}\text { Mean } \\
\text { Square }\end{array}$ & F & Sig. \\
\hline 1 & Regression & 351.384 & 117.128 & 41.877 & $.000^{\mathrm{a}}$ \\
\hline & Residual & 212.566 & 2.797 & & \\
\hline & Total & 563.950 & & & \\
\hline
\end{tabular}

Hasil pengujian model regresi diperoleh nilai $\mathrm{F}$ hitung sebesar 41.877 dengan signifikan 0,000 dengan nilai a ( batas signifikan) adalah 0,05 sehingga dapat diektahui bahwa $0,000<0,05$ maka model analisis regresi ini dinyatakan signifikan. Hal ini dinyatakan HO ditolak dan dapat disimpulkan bahwa hipotesis menyatakan bahwa keputusan konsumen yang terdiri dari lokasi promosi penjualan dan kualitas layanan.

\section{Hasil Uji Parsial (Uji t)}

Pengujian ini dilakukan untukmengetahui seberapa besar pengaruh variabel indipenden atau variabel bebas (lokasi promosi penjualan dan kualitas layanan) . secara parsial berpengaruh signifikan terhadap variabel dependen atau variabel terikat (keputusan konsumen). Uji parsial atau uji $t$ ini dilakukan dengan melakan perbandingan nilai $t$ dengan taraf signifikan atau $a=0.05$. uji parsial digunakan sebagai alat untuk menguji hipotesis variabel keputusan konsumen yang terdiri dari lokasi promosi penjualan dan kualitas layanan. Hasil uji t atau uji parsial lebih jelasnya dapat dilihat pada penjelasan dibawah ini :

\section{1) Variabel Lokasi (X1)}

Dari hasil pengolahaan data yang dilakukan, dapat dilihat besar probabilitas signifikan lokasi (X1) sebesar $0,000<$ a 0,05 maka secara statistik dalam penelitian ini variabel lokasi secara parsial 
berpengaruh signifikan terhadap keputusan konsumen berbelanja di Transmart Carrefour Kota Palu.

2) Variabel Promosi Penjualan

Berdasarkan hasil pengolahan data y dilakukan, dapat dilihat besar probabilitas signifikan lokasi (X2) sebesar 0,30 < a 0,05 maka secara statistik dalam penelitian ini variabel lokasi secara parsial berpengaruh signifikan terhadap keputusan konsumen berbelanja di Transmart Carrefour KotaPalu

3) Variabel kualitas Layanan

Berdasarkan hasil pengolahan data y dilakukan, dapat dilihat besar probabilitas signifikan lokasi (X2) sebesar 0,30 < a 0,05 maka secara statistik dalam penelitian ini variabel lokasi secara parsial berpengaruh signifikan terhadap keputusan konsumen berbelanja di Transmart Carrefour Kota Palu.

\section{Uji Koefisian Determinasi $\left(\mathbf{R}^{2}\right)$}

Agar dapat mengetahui seberapa besar kontribusi variabel indipendnen (lokasi, poromi penjualan ,dan kualitas layanan ) terhadap variabel dependen (keputusan konsumen ) digunakan nilai hasil uji $\mathrm{R}^{2}$.

Tabel 10

Uji Koefisien Dertiminasi $\left(\mathbf{R}^{2}\right)$

\begin{tabular}{|c|c|c|c|c|}
\hline Model & $\mathrm{R}$ & $\mathrm{R}$ square & Adjusted R square & $\begin{array}{c}\text { Std. Error of the } \\
\text { Estimate }\end{array}$ \\
\hline 1 & $789^{\mathrm{a}}$ & 623 & 608 & 1.672 \\
\hline
\end{tabular}

Sumber data diolah

Dari hasil pengolahan data dapat dilihat bahwa nilai R dan Adjusted $R$ Square masing-masing 0,789 dan 0,623 dijelaskan sebagai berikut :

1. Nilai Adjusted atau kofisien determinasi memiliki nilai sebesar 0,608 . nilai tersebut menunjukan besarnya pengaruh variabel indipendne secara keseluruhan (simultan ) terhadap variabel dependen, sehingga dapat diketahui bahwa secara keseluruhan (pengaruh variabel indipenden terhadap variabel dependen dalam penelitian ini adalah sebesar 78\% atau dapat pula diartikan $46 \%$ variasi dari variabel lokasi, promosi penjualan dan kulaitas layanan sedangkan sisanya $22 \%(100 \%$ $78 \%$ ) dijelaskan oleh pengaruh variabel-variabel lain yang tidak disetakan dalam penelitian.

2. Koefisien korelasi (R) memiliki nilai sebesar 0, 789 yang berarti bahwa variabel yang diteliti yaitu lokasi, promosi penjualan, dan keputusan konsumen memiliki hubungan yang kuat terhadap variabel terikat sebesar $0.78 \%$

\section{Pembahasan Hasil Penelitian}

\section{Pengaruh Lokasi $\left(\mathrm{X}_{1}\right)$ Terhadap Keputusan Konsumen Berbelanja Di Transmart Careffour Palu}

Pengaruh lokasi terhadap keputusan konsumen dalam mengambil keputusan berbelanja di Transmart Carrefour palu dari data yang ditunjukan bahwa nilai terbesar yang diperoleh dari hasil pengaruh lokasi ialah 4,46\% menunjukan hasil penelitian signifikan terhadap keputusan konsumen berbelanja di Transmart Carrefour Palu disebab lokasi Transmart Carrefour mudah dijangkau oleh masyarakat disebabkan lokasinya berada didalam kota Palu. sesuai dengan pendapat Fandy Tjiptono (2002:92) lokasi adalah tempat perusahaan beroperasi atau tempat perusahaan melakukan kegiatan untuk menghasilkan barang atau jasa yang mementikan segi ekonominya.

\section{Pengaruh Promosi Penjualan $\left(\mathrm{X}_{2}\right)$ Terhadap Keputusan Konsumen Berbelanja Di Transmart Careffour Palu}

Promosi penjualan merupakan salah satu aspek terhadap keputusan konsumen dalam mengambil keputusan berbelanja di Supermarket khususnya Transmart Carrefour Palu. Promosi yang dilakukan melalui promo menggunakan kartu, promo hebat akir pekan, promo beli 2 gtatis 1, promo menggunakan sampel gratis, dan promo tukar poin belanja sangat mendukung menarik minat masyarakat untuk berbelanja, promosi penjualan yang memberikan diskon sebesar $10 \%$ oleh Transmart Carrefour menjadi salah satu ciri untuk membedakan dengan Supermarket yang ada di 
Palu.Hal ini juga didukung oleh penelitian terdahulu Yuda Melisa "Pengaruh Bauran Pemasaran Ritel Terhadap Keputusan Pembelian Ulang Konsumen Mega Prima Swalayan Payakumbuh" menunjukan bahwa sebuah promosi penjualan merupakan aspek penting untuk menarik minat konsumen berbelanja di Carrefour secara berulang-ulang.

\section{Pengaruh Kualitas Layanan ( $\left.\mathrm{X}_{3}\right)$ Terhadap Keputusan Konsumen Berbelanja Di Transmart Carrefour Palu}

Pengaruh kualitas layanan terhadap keputusan konsumen dalam mengambil keputusan berbelanja di Transmart Carrefour palu ialah variabel penting ketiga dengan nilai yang dihasilkan sebesar $4.41 \%$ berdasarkan hasil penelitian yang ditunjukan berpengaruh signifikan dan didukung oleh penelitian terdahulu yaitu :Bayu Yulianto "Pengaruh produk, harga, promosi, layanan terhadap keputusan konsumen membeli sepeda motor kawasaki "Tujuan dari penelitian ini adalah untuk mengetahui variabel produk, harga, promosi dan layanan. mengatakan Hasil pengujian secara simultan menunjukkan pengaruh variabel produk, harga, promosi,dan layanan secara bersama-sama keputusan konsumen membeli sepeda motor pada Dealer sepedamotor Kawasaki Ngagel di Surabaya adalah signifikan sesuai dengan pendapat Tjiptono, dalam (Cristiani D. Manengal, 2015:2), mengatakan bahwa kualitas layanan adalah Kualitas layanan adalah tingkat keunggulan (excellence) yang diharapkan dan pengendalian atas keunggulan tersebut untuk memenuhi keinginan pelanggan.

\section{KESIMPULAN DAN SARAN}

\section{Kesimpulan}

Berdasarkan hasil analisis regresi dan pembahasan dapat ditarikkesimpulan sebagai berikut :

1. Lokasi, promosi penjualan dan kualitas layanan secara simultan berpengaruh signifikan terhadap

2. keputusan konsumen berbelanja diTransmart Carrefour Palu.

3. Promosi penjualan secara parsial berpengaruh signifikan terhadapkeputusan berbelanja di TransMart Carrefour palu.

4. Kualitas layanan secara parsial berpengaruh signifikan terhadapkeputusan Konsumen berbelanja di Transmart Carrefour Palu.

5. Lokasi secara parsial tidak berpengaruh signifikan terhadap keputusankonsumen berbelanja di Transmart Carrefour Palu.

\section{Saran}

Berdasarkan uraian kesimpulan dalam penelitian ini, dapat dikemukakansaran-saran sebagai berikut :

1. Promosi penjualan adalah sesuatu yang dilakukan oleh pihak perusahanuntuk menarik konsumen berbelanja ditempatnya. Promosi yang ditawarkan oleh Transmart Carrefour ialah memberikan discount potonganharga 10\% dengan mengunakan kartu kredit bank Mega. TransmartCarrefour selalu mengingatkan konsumenya diakir pekan, bulan dan tahundengan cara memberikan discount besar-besaran hal tersebut dapat menjadikeputusan konsumen datang berbelanja di Transmart Carrefour Palu.

2. Kualitas layanan adalah salah satu kunci keberhasilah suatu perusahandimana karyawannya selalu sopan, memberikan senyum , berpenampilanrapi. Dibandingkan dengan perusahan lain Transmart Carrefour mampumemberikan pelayanan terbaik kepada konsumen yang datang berbelanja.Hal tersebut dapat memberikan keputusan konsumen berbelanja kembali diTransmart Carrefour Palu.

3. Lokasi adalah salah satu penunjang sebuah perusahaan yang akandidirikan, meski lahan parkir yang dimiliki Transmart Carrefour sangatkecil tidak menjadikan Transmart Carrefour mudah untuk disaingin olehperusahaan yang memiliki usaha sama. Letak lokasi yang strategis beradadi tengah kota, pemukiman warga, perkantoran, sekolah, menjadikanTransmart Carrefour sangat mudah dijumpai oleh konsumen hal tersebutdapat memberikan kuputusan konsumen untuk datang kembali berbelanja. 


\section{REFERENSI}

Abbdullah, Thamrin, danTantri Francis, 2014. ManajemenPemasaran, PT. RajagrafindoPersada, Jakarta.

Assauri, Sofjan, 2014, ManajemenPemasara: Dasar, KonsepdanStrategi, PT.RajaGrafindoPersada, Jakarta.

Adam, Rosida P, 2010. Manajemen Pemasaran, Lembaga Pengkajian Pembaruan Hukum dan Kebijakan Publik (LP2HKP), Palu.

Antari Mariska Ria Kadek, Ketut Dunia, Luh Indrayani. Pengaruh Lokasi Dan Harga Terhadap Keputusan Berbelanja Pada Mini Market Sastra ,As Tabanan Singaraja Vol 4 No 1. Tahun 2014

Charthy,Mc.,and W.D Perreaulth, JR., 2006. Dasar-DasarPemasaran, EdisiKelima, PT. Erlangga, Jakarta.

Cristina, (2011), DimensiKualitasLayanan http://ejournal.uajy.ac.id/654/3/2EM16485.pdf

Firdaus, 2004.StatistikParametrik; Regresi Linear BergandadanProblematikanya, PT. RinekaCipta, Jakarta.

Ghozali, Imam, 2006. AplikasiAnalisis Multivariate Dengan Program SPSS, BadanUniversitas di Ponegoro, Semarang.

Gujarati, Damodar, 2003. Basic Ekonometrics, McGraw-Hill Book Company, New York, USA.

Jasfar, Farida, 2005. ManajemenJasa, Ghalia Indonesia, Jakarta. 